\title{
Mycostimulation in a glyphosate treated arable soil: implications on the yield and agronomic characters of Talinum fruticosum (L.) Juss
}

\section{${ }^{* 1}$ SANYAOLU, ADENIYI AKEEM ADETOLA; ${ }^{1}$ CORDELIA BUKOLA UDOFOT}

\author{
${ }^{1}$ Department of Botany and Ecological Studies, Faculty of Science, \\ University of Uyo, Uyo, Akwa Ibom State, Nigeria \\ †Corresponding Author's email: adeniyisanyaolu@uniuyo.edu.ng
}

\begin{abstract}
The use of pesticide, although increases agricultural yield and improves public health is also fraught with a number of ecologic, agronomic and health concerns. This research investigated the impact of an ex-situ mycostimulation of one of the in-situ soil fungi on some agronomic characters and yield of Talinum fruticosum planted on a herbicide treated soil. Experimental site was laid out in a $3 \times 8$ Randomised Complete Block Design (RCBD). Amongst other fungal species found in the soil, Paecilomyces variotii was selected for multiplication and reintroduction to the field 96 hours after the application of glyphosate and 48 hours after the transfer of T. fruticosum from the nursery. Data on agronomic parameters were taken between the $1-6$ weeks after planting (WAP) while data on the biomass yield $\left(\mathrm{kgha}^{-1}\right)$ was taken (on harvesting) at 6 WAP. Data were mean values from 8 replicates and analysed using the statistical package IBM SPSS version 20. Mean values were separated for statistical significance at $95 \%$ confidence interval, using the Least Significant Difference (LSD). The results showed that the Treatments had significant (P<0.05) effects on height of plants, density of plants, size of leaves and internode spacing at the different WAP as well as the biomass and yield of Talinum at 6 WAP. The results obtained from the present study thus further reaffirm the crucial role of fungi as nature's original recyclers. If properly managed and stimulated, fungi can contribute significantly to improving soil health, thus improving food security in a sustainable manner. C JASEM
\end{abstract}

https://dx.doi.org/10.4314/jasem.v21i6.23

Keywords: Mycoaugmentation, herbicide, Talinum fruticosum, Paecilomyces variotti, Soil health.

The most common use of pesticides is as Plant or Crop protection product. In general, pesticides are known to protect plants from damages caused by insects, molluscs, weeds, fungi, nematodes, birds, rodents etc (Ellegaard-Jensen, 2012). Through the use of pesticides, there has been a significant improvement in agricultural productivity (Kuo and Regan, 1999; Helweget al., 2003). The corollary to this improvement in yield is a corresponding reduction in the prices of food on a global scale. The use of pesticide is global and extensive in nature (Ellegaard-Jensen, 2012). Of this global usage, herbicides account for the largest part of the total pesticide use (Grubeet al., 2011).

According to Braschiet al. (2000), active substances found in many herbicides may hamper the rate of a series of biochemical processes and microbial growth in the soil. These modifications in the count and activity of soil microorganisms may lead to upsetting the biological equilibrium of the soil environment, thus precipitating a concomitant decrease in soil fertility and the biological productivity of the plants cultivated on such soils.

In view of all of these, this research sets out to investigate the impact of an ex situ stimulation of the population density of one of the resident fungal species in an arable land under the influence of glyphosate, on the biomass yield and some agronomic characters of $T$. fruticosum planted on this soil.

\section{MATERIALS AND METHODS}

Isolation of fungi and preparation of pure culture from the experimental plot: One gram of topsoil sample was aseptically taken from each of the 8 Blocks in the field and thoroughly mixed together to form a composite sample.This bulked sample was transferred under an aseptic condition to the laboratory, where serial dilution using sterile distilled water was then carried out on the sample to the 6th concentration. One or two drops of the solution from each concentration of the serially diluted soil sample was aseptically placed (using sterile pipettes) into a sterile plate to which freshly prepared sterile Potato Dextrose Agar-PDA (containing antibiotic and lactic acid) was added. The set up for each concentration was thereafter incubated for between 1- 2 weeks until growth containing mixed species was observed in each Plate. Distinct fungal colonies from each plate was thereafter repeatedly sub cultured in fresh sterile PDA plates until pure cultures containing only one type of growth in each plate was obtained. After this, the pure plate that showed the most aggressive growth during the isolation study in the laboratory was identified as Paecilomyces variotii. This organism $-P$. Variotii was thereafter mass cultured to obtain 400 pure plates of same. Spores from all the pure plates containing $P$. variotii were aseptically harvested by scrapping each pure plate soaked in 10 
$\mathrm{ml}$ of sterile distilled water with pre sterilized spatulas until only the PDA was left in the plate.

Re-introduction of harvested fungal spores ( $P$. variotii) to the experimental site: At the end of the harvesting of the spores of $P$. variotii in the laboratory, about $4000 \mathrm{ml}$ of suspension of sterile distilled water containing the spores of this fungus was collected into a pre sterilized, fine nozzle watering can. The content of this watering can was thereafter applied to the different Treatment cells in each of the Blocks earmarked to receive the fungal spores. The portions marked out to not receive the spore of this fungus were equally sprayed with about $4000 \mathrm{ml}$ of sterile distilled water using another pre sterilized, fine nozzle watering can.

Treatments Applied and the Layout of experimental site: The experimental field was laid out in a $3 \times 8$ Randomized Complete Block Design (RCBD) containing 3 Treatments each in a total of 8 Blocks. The size for each Treatment cell in each Block was $1 \mathrm{~m}^{2}$. Each of these 3 Treatments were randomly assigned on each of the $1 \mathrm{~m}^{2}$ cell within the 8 Blocks. Treatments assigned were as follow: Treatment 1 (T1) $=P$. variotii - glyphosate $+T$. fruticosum; Treatment $2(\mathrm{~T} 2)=-P$. variotii + glyphosate $+T$. fruticosum and Treatment $3(\mathrm{~T} 3)=P$. variotii + glyphosate $+T$. fruticosum.

Where+ indicate presence or addition and - indicate not added or not present.

Planting of $T$. fruticosum and application of glyphosate on the experimental site: After the layout of the experimental site, and prior to the reintroduction of $P$. variotti to the site, glyphosate was applied at the recommended rate to the required portions on each Block. Two days after the application of this herbicide, T. fruticosum seedlings were transplanted from the nursery into the experimental site, while the fungus $(P$. variotti) was re-introduced into the required portions on the field 4 days and 2 days after the application of glyphosate and the transplanting of $T$. fruticosum seedlings respectively.

Data were taken on the T. fruticosum at between 1-6 weeks after planting (WAP) on such parameters as plant height, plant density, leaf size and internode space by measuring with a ruler while data on the biomass yield $\left(\mathrm{kgha}^{-1}\right)$ were taken on harvesting at 6 WAP by carefully uprooting each plant, and their roots washed under a running tap before weighing on the Mettler top loading weighing balance.
Processing and analyses of data: Data on the mean value of biomass yield was thereafter converted from gram per square metre to kilogram per hectare.Data reported for each Treatment was mean values from 8 replicates. These data were analysed using the IBM SPSS Statistics version 20 software statistical package. Using the same software package, mean values were separated for statistical significance at 95\% confidence interval, using the Least Significant Difference (LSD).

\section{RESULTS AND DISCUSSION}

The results for plant height show that the ex situ stimulation of $P$. variotti and the use of glyphosate had a significant $(\mathrm{P}<0.05)$ effect on the height of $T$. fruticosum at each WAP (Table 1), where plants in T1 consistently (in each of the WAP) had the least mean height while plants in $\mathrm{T} 3$ had the highest mean height.

The results in Table 2 show that the Treatments had a significant $(\mathrm{P}<0.05)$ effect on the density of $T$. fruticosum at the different WAP with plants in T3 having the highest mean density.

Following a similar trend, Table 3 show that there were significant $(\mathrm{P}<0.05)$ differences in the mean leaf size among the 3 Treatments at each of the WAP, with the lowest and highest mean values at each WAP belonging to $\mathrm{T} 1$ and $\mathrm{T} 3$ respectively.

Presenting a dissimilar picture from the already established trend, results from Table 4 show that T1 had the highest mean internode length at each of the WAP. The mean values recorded for $\mathrm{T} 1$ for this parameter at each of the WAP were significantly $(\mathrm{P}<0.05)$ higher than those of $\mathrm{T} 2$, while those for $\mathrm{T} 2$ were also significantly higher $(\mathrm{P}<0.05)$ than the mean values recorded for $\mathrm{T} 3$.

The results as shown in Figure 5 reveal that the Treatments had a significant $(\mathrm{P}<0.05)$ effect on biomass yield. The highest mean yield was obtained for T3 while the lowest was for T1.

Table 1: Mean Plant Height at 1-6 WAP

\begin{tabular}{llll} 
& \multicolumn{2}{c}{ TREATMENTS } & \\
Weeks After & T1 & T2 & T3 \\
Planting (WAP) & & & \\
\hline 1 & $4.71^{\mathrm{a}}$ & $5.61^{\mathrm{b}}$ & $10.16^{\mathrm{c}}$ \\
2 & $5.21^{\mathrm{a}}$ & $6.7^{\mathrm{b}}$ & $15.28^{\mathrm{c}}$ \\
3 & $5.56^{\mathrm{a}}$ & $9.59^{\mathrm{b}}$ & $15.8^{\mathrm{c}}$ \\
4 & $5.75^{\mathrm{a}}$ & $10.28^{\mathrm{b}}$ & $16.15^{\mathrm{c}}$ \\
5 & $6.13^{\mathrm{a}}$ & $11.69^{\mathrm{b}}$ & $16.4^{\mathrm{c}}$ \\
6 & $6.59^{\mathrm{a}}$ & $12.54^{\mathrm{b}}$ & $17.85^{\mathrm{c}}$ \\
\hline
\end{tabular}

Values carrying different superscripts along the column are significantly different at $\mathrm{p}<0.05$ 
Table 2: Mean Plant density at 1-6 WAP TREATMENTS

\begin{tabular}{llcc}
$\begin{array}{l}\text { Weeks After } \\
\text { Planting (WAP) }\end{array}$ & $\mathrm{T} 1$ & $\mathrm{~T} 2$ & $\mathrm{~T} 3$ \\
\hline 1 & $15^{\mathrm{a}}$ & $21.38^{\mathrm{b}}$ & $32.25^{\mathrm{c}}$ \\
2 & $12.25^{\mathrm{a}}$ & $18.62^{\mathrm{b}}$ & $32.25^{\mathrm{c}}$ \\
3 & $4.5^{\mathrm{a}}$ & $18.67^{\mathrm{b}}$ & $32.25^{\mathrm{c}}$ \\
4 & $4.5^{\mathrm{a}}$ & $18.67^{\mathrm{b}}$ & $32.25^{\mathrm{c}}$ \\
5 & $4.1^{\mathrm{a}}$ & $18.67^{\mathrm{b}}$ & $32.25^{\mathrm{c}}$ \\
6 & $3.7^{\mathrm{a}}$ & $18.67^{\mathrm{b}}$ & $32.25^{\mathrm{c}}$ \\
\hline
\end{tabular}

Values carrying different superscripts along the same column are significantly different at $\mathrm{p}<0.05$

Table 3: Mean leaf size at 1-6 WAP

\begin{tabular}{lccc} 
& \multicolumn{3}{c}{ TREATMENTS } \\
Weeks After & T1 & T2 & T3 \\
Planting (WAP) & & & \\
\hline 1 & $2.46^{\mathrm{a}}$ & $2.95^{\mathrm{b}}$ & $3.78^{\mathrm{c}}$ \\
2 & $2.85^{\mathrm{a}}$ & $3.17^{\mathrm{b}}$ & $3.99^{\mathrm{c}}$ \\
3 & $2.98^{\mathrm{a}}$ & $3.66^{\mathrm{b}}$ & $4.4^{\mathrm{c}}$ \\
4 & $3.11^{\mathrm{a}}$ & $4.2^{\mathrm{b}}$ & $4.67^{\mathrm{c}}$ \\
5 & $3.37^{\mathrm{a}}$ & $4.36^{\mathrm{b}}$ & $4.77^{\mathrm{c}}$ \\
6 & $3.39^{\mathrm{a}}$ & $4.54^{\mathrm{b}}$ & $4.98^{\mathrm{c}}$ \\
\hline
\end{tabular}

Values carrying different superscripts along the same column are significantly different at $\mathrm{p}<0.05$

Table 4: Mean Internode length at 1-6 WAP

\begin{tabular}{llll} 
& \multicolumn{3}{c}{ TREATMENTS } \\
Weeks After & T1 & T2 & T3 \\
Planting (WAP) & & & \\
\hline 1 & $1.83^{\mathrm{a}}$ & $1.48^{\mathrm{b}}$ & $1.46^{\mathrm{c}}$ \\
2 & $1.9^{\mathrm{a}}$ & $1.67^{\mathrm{b}}$ & $1.69 \mathrm{c}$ \\
3 & $2.23^{\mathrm{a}}$ & $1.71^{\mathrm{b}}$ & $1.7^{\mathrm{c}}$ \\
4 & $2.41^{\mathrm{a}}$ & $1.71^{\mathrm{b}}$ & $1.71^{\mathrm{c}}$ \\
5 & $2.44^{\mathrm{a}}$ & $1.74^{\mathrm{b}}$ & $1.72^{\mathrm{c}}$ \\
6 & $2.44^{\mathrm{a}}$ & $1.77^{\mathrm{b}}$ & $1.75^{\mathrm{c}}$ \\
\hline
\end{tabular}

Values carrying different superscripts along the same column are significantly different at $\mathrm{p}<0.05$

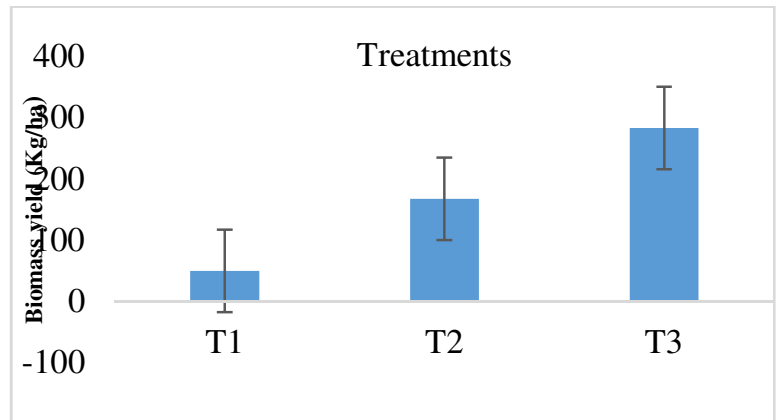

Fig 1: Mean Biomass yield for Treatments at harvest

Many of the chemicals used in pesticides are persistent soil contaminants, whose impact may endure for decades and adversely affect soil conservation (Yadav et al.., 2015). This notwithstanding, the uncontrolled growth of weeds in competition with cultivated species has been reported to have caused a significant loss in the growth and yield of these cultivated plants, sometimes, with losses as high as between over 57 to over $73 \%$ being reported (Amare, 2014). The results obtained in this work corroborates the adverse effect that competition by weeds have on the growth indices and yield of cultivated species, where for all the parameters evaluated (except internode length), plants from T1 showed significantly lower values on account of competition by weeds, as opposed to the two other Treatments where weeds were controlled with the use of the glyphosate.

Results obtained in present study (with respect to T3) agree with the reports of earlier workers with respect to the role of saprophytic fungi in soil mineralization process and plant productivity. Saprotrophic fungi (such as $P$. variotii) are known to produce an impressive range of extracellular enzymes (Kjøller and Struwe, 2002) that are vital for degradation of organic pollutants (Ellegaard-Jensen, 2012). In this regard, the role of saprophytic fungi in soil mineralization process has been extensively documented (Ekundayo and Obire, 1987; Vwioko et al., 2006; Covino et al., 2010). By this mineralization process, elevation in soil nutrient status, which resulted in better growth of plants, has severally been reported by earlier workers (Adams and Ellis, 1960; Udo and Fayemi, 1975; Egunjobi and Onweluzor, 1979; Gadd, 2007).

Conclusion: It will therefore be rational to conclude that results obtained from this work further reaffirm the crucial role of fungi as nature's original recyclers. If properly managed and stimulated, fungi can contribute significantly to improving soil health, thus improving food security in a sustainable manner.

\section{REFERENCES}

Adams, RS; Ellis, RJ (1960). Some physical and chemical changes in soil brought about by saturation with natural gas. Proceeding of American Soil Science Society 24: 41-45.

Amare, T (2014). Effect of weed management methods on weeds and wheat (TriticumaestivumL.) yield. African Journal of Agricultural Research 9(24): 1914 - 1920. DOI: 10.5897/AJAR2013.8288

Braschi, I; Pusino, A; Gessa, C; Jean-Marc, B (2000).Degradation of Primisulfuron by a Combination of Chemical and Microbiological Processes.Journal of Agricultural and Food Chemistry 48(6): 2565 -2571.

Covino, S; Svobodova, K; Křesinova, Z; Petruccioli, M; Federici, F; D’Annibale, A; Čvančarova, M; 
Cajthaml, $T$ (2010). In vivo and in vitro polycyclic aromatic hydrocarbon degradation by Lentinus tigrinus (Panus.) CBS 577.79.Bioresources Technology 101: 30043014.

Egunjobi, JK; Onweluzo, BS (1979). Litter fall, mineral turnover and litter accumulation in Pinus caribaea L. stands at Ibadan, Nigeria. Biotropica 11(4): 251-255.

Ekundayo, JA; Obire, O (1987). Use of Indigenous microorganisms in ridding theenvironment of spilled oil. Proceeding of the International Seminar on PetroleumIndustry and the Nigerian Environment: 139-148.

Ellegaard-Jensen, L (2012). Fungal degradation of pesticides-construction of microbial consortia for bioremediation. $\mathrm{PhD}$ Thesis, The PhD School of Science, Faculty of Science, University of Copenhagen, Denmark: 109pp.

Gadd, GM (2007). Geomycology: biogeochemical transformations of rocks, minerals, metals and radionuclides by fungi, bioweathering and bioremediation. Mycological Research 111: 349.

Grube, A; Donaldson, D; Kiely, T; Wu, L (2011). Pesticides Industry Sales and Usage. U.S. Environmental Protection Agency.

Helweg, C; Bettg, B; Peter, B; Torben, M; Dorte, R (2003) Fate of pesticides in surface waters,

Laboratory and Field Experiments. Danish Environmental Protection Agency: 135pp.
Kjøller, AH; Struwe, S (2002). Fungal communities, succession, enzymes and decomposition. In: Burns, R.G. and Dick, R.P. (Eds.). Enzymes in the environment. Marcel Dekker, New York: 284pp.

Kuo, WS; Regan Sr, RW (1999). Removal of pesticides from rinsate by adsorption using agricultural residuals as medium. Journal of Environmental Science and Health, Part B 34(3): 431-447

Udo, EJ; Fayemi, AAA (1975). The effects of oil pollution on soil, germination, growth and nutrient uptake of Okra. Journal of Environmental Quality 4(4): 537-540.

Vwioko, DE; Anoliefo, GO; Fashemi, DS (2006) Metals concentration in plant tissues of Ricinus communis L. (Castor Oil) grown in soil contaminated with spent lubricating oil. Journal of Applied Science and Environmental Management 10: 127-134.

Yadav, IS; Devi, NL; Syed, JH; Cheng, Z; Li, J; Zhang, G; Jones, KC (2015). Current status of persistent organic pesticides residues in air, water, and soil, and their possible effect on neighboring countries: A comprehensive review of India. Science of theTotal Environment 511: $123-137$ 